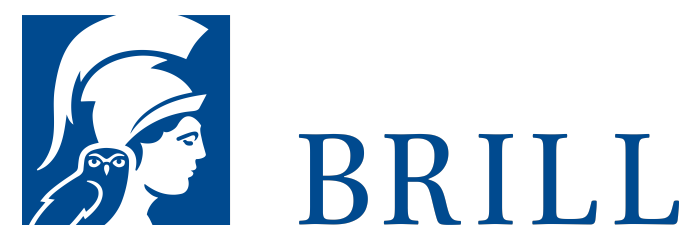

\title{
Atomkrieg und andere Katastrophen
}

Zivil- und Katastrophenschutz in der Bundesrepublik und Großbritannien nach 1945

Author: Martin Diebel

Mehr als nur ein Bunker: Zivilschutz ist eine Form der Sicherheitspolitik, deren Betrachtung einen umfassenden Einblick in den sozialen sowie politischen Zustand westlicher Industriegesellschaften im 2o. Jahrhundert verspricht. Krieg, Überschwemmung und Atomkraft - westliche Gesellschaften standen nach 1945 vielfältigen Bedrohungen gegenüber. Sicherheit avancierte zu einem Schlüsselbegriff des 20. Jahrhunderts. Dieser Spur folgend, zeichnet Martin Diebel die Geschichte des Zivil- und Katastrophenschutzes in der Bundesrepublik und Großbritannien nach. Es ist eine Erzählung des Wandels, dessen Ursprünge bis weit in den Zweiten Weltkrieg zurückreichen. Das Buch geht dabei über die Grenzen des Ost-West-Konfliktes hinaus. Zivilschutz war weit mehr als eine Antwort auf die atomare Bedrohung. Er war Ausdruck sich wandelnder gesellschaftlicher Sicherheitsvorstellungen seit den 1970er Jahren. Eine Entwicklung, die angesichts terroristischer Bedrohung und ökologischer Katastrophen bis in die jüngste Gegenwart reicht.

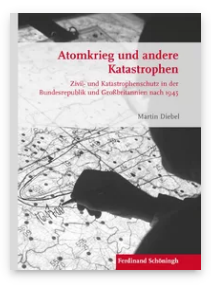

Pages: 348

Seiten

Language:

German

Subjects:

Contemporary

History, History

Publisher: Brill |

Schöningh

Series:

Krieg in der

Geschichte,

Volume: 99

E-Book (PDF)

Released online:

17 Nov 2017

ISBN: 978-3-

657-78745-6

List price

Hardback

Publication date: o8 Sep 2017

ISBN: 978-3506-78745-3

List price 
Biographical Note

Martin Diebel ist wissenschaftlicher Mitarbeiter am Zentrum für Zeithistorische Forschung Potsdam.

For more information see brill.com

\author{
Order information: Order online at brill.com \\ +44330 3330049 | customerservices@brill.com \\ Submission information: brill.com/authors
}

Titles published by Brill | Fink, Brill | mentis or Brill | Schöningh:

+49(o)71 5413279216 | brill@brocom.de 